\title{
ResearchArticle
}

\section{Study of morphological and genetical variabilities for improving forage production in oat}

\author{
R. E. KAKAD, D.R. SAPKAL, G. K. THAKARE AND A. G. IRATKAR
}

\begin{abstract}
SUMMARY
Oat (Avena sativa L.), one of the important dual purpose crops of the world is grown for food and forage purpose. In India it is exclusively grown as fodder. Sixteen genotypes of oat grown at the Central Research Farm of Bidhan Chandra Krishi Viswavidyalaya, Gayeshpur, Nadia, W. Bengal In the Rabi season of 2010-11 to estimate the direct and indirect effect of the component characters on the dry matter production. Considering the mean values for time taken for germination and other twenty five different forage yield characters, the genotypes OL-1709, JHO-2010-2, Kent, NDO- 729, OS-6 and JO-0397 were found to produce significantly higher total dry weight per tiller at 50 per cent flowering (time of harvest). A close proximity between GCV and PCV were obtained for the characters like, plant height at 20 and 40 days age of the crop and also at 50 per cent flowering, fresh weight of leaf, dry weight of leaf, fresh weight of stem, dry weight of stem per tiller at 40 days, total dry weight of stem per tiller at 40 days, fresh weight of stem, dry weight of stem per tiller at 50 per cent flowering, fresh weight of flag leaf, dry weight of flag leaf, flag leaf area, Ch 'a', Ch 'b' and total chlorophyll content and crude protein percentage revealed the characters were not much influenced by environment. These characters had very high values for broad sense heritability. Some of these characters like dry weight and fresh weight of stem per tiller at 40 days, fresh and dry weight of stem per tiller at 50 per cent flowering, chlorophyll 'b' content; fresh and dry weight of flag leaf produced high magnitude of GA in terms of percentage of mean. All these characters indicated to be controlled by additive gene action. Therefore, direct selection in desired direction may be practiced for improvement of the characters on the basis of phenotype can be done.
\end{abstract}

Key Words : Morphological, Genetical variabilities, Forage production

How to cite this article : Kakad, R.E., Sapkal, D.R., Thakare, G. K. and Iratkar, A.G. (2017). Study of morphological and genetical variabilities for improving forage production in oat. Internat. J. Plant Sci., 12 (1): 1-14, DOI: 10.15740/HAS/IJPS/12.1/1-14.

Article chronicle : Received : 13.06.2016; Revised : 05.11.2016; Accepted : 01.12.2016

\section{MEMBERS OF THE RESEARCH FORUM}

Author to be contacted :

R.E. KAKAD, Department of Genetics and Plant Breeding, Bidhan Chandra Krishi Viswavidyalaya, Mohanpur, NADIA (W.B.) INDIA

Address of the Co-authors:

D.R. SAPKAL, G.K. THAKARE AND A.G. IRATKAR, Department of

Genetics and Plant Breeding, Bidhan Chandra Krishi Viswavidyalaya, Mohanpur, NADIA (W.B.) INDIA 